\title{
Assessment of Age-Dependent Effective Dose and Toxicity Risks of 226Ra and 228Ra In River Water Samples In Ondo State. Nigeria
}

Oladele Ajayi ( $\sim$ samuelajayi98@yahoo.com )

Federal University of Technology, Akure. Nigeria

Olusegun Omogunloye

Olusegun Agagu University of Science and Technology, Okitipupa.

\section{Research Article}

Keywords: Activity concentration, Radiological hazard, River water, Age-dependent effective dose, Lifetime cancer risk, Toxicity risks

Posted Date: January 23rd, 2021

DOI: https://doi.org/10.21203/rs.3.rs-150702/v1

License: (c) (i) This work is licensed under a Creative Commons Attribution 4.0 International License.

Read Full License 


\section{ASSESSMENT OF AGE-DEPENDENT EFFECTIVE DOSE AND TOXICITY RISKS}

OF ${ }^{226}$ Ra AND ${ }^{228}$ Ra IN RIVER WATER SAMPLES IN ONDO STATE. NIGERIA

Ajayi O.ladele Samuel ${ }^{\mathrm{a} 1}$ and Omogunloye Olusegun Yemi ${ }^{2}$

${ }^{1}$ Department of Physics, Federal University of Technology, P.M.B. 704, Akure. Ondo State. Nigeria.

aEmail: samuelajayi98@yahoo.com; osajayi@futa.edu.ng

${ }^{2}$ Department of Physical Sciences

Olusegun Agagu University of Science and Technology, Okitipupa. Ondo State. Nigeria.

oy.omogunloye@ osustech.edu.ng

${ }^{\text {a }}$ Corresponding author 


\begin{abstract}
Activity concentrations of natural radionuclides in some river waters in southwestern Nigeria were measured using high-purity germanium (HPGe) detector. The activity concentrations ranged from 0.12 to $2.31,0.17$ to 2.85 , and 7.86 to $65.51 \mathrm{~Bq}^{-1}$ for ${ }^{226} \mathrm{Ra}$, ${ }^{228} \mathrm{Ra}$, and ${ }^{40} \mathrm{~K}$ respectively. The calculated mean of the total annual effective dose were 9.86 , $2.46,1.71,2.43,5.74$ and $0.99 \mathrm{mSv}^{-1}$ for age groups $\leq 1 \mathrm{y}, 1-2 \mathrm{y}, 2-7 \mathrm{y}, 7-12 \mathrm{y}, 12-17 \mathrm{y}$, and $>17 \mathrm{y}$ respectively. Estimated cancer mortality and morbidity risks ranged from $0.04 \times 10^{-3}$ to $0.77 \times 10^{-3}$ with a mean of $0.42 \times 10^{-3}$ and $0.04 \times 10^{-3}$ to $0.80 \times 10^{-3}$ with a mean of $0.44 \times 10^{-3}$ respectively for ${ }^{226} \mathrm{R}$ while they ranged from $0.11 \times 10^{-3}$ to $1.89 \times 10^{-3}$ with a mean of $0.96 \times 10^{-3}$ and $0.16 \times 10^{-3}$ to $2.66 \times 10^{-3}$ with a mean of $1.38 \times 10^{-3}$ respectively for ${ }^{228} \mathrm{Ra}$. The lifetime average daily dose (LADD) of ${ }^{226} \mathrm{Ra}$ and ${ }^{228} \mathrm{Ra}$ ranged from $9.39 \times 10^{-14} \mu \mathrm{g} \mathrm{kg}^{-1} \mathrm{~d}^{-1}$ to $181.01 \times 10^{-14} \mu \mathrm{g} \mathrm{kg}^{-1} \mathrm{~d}^{-1}$ with a mean of $100.06 \times 10^{-14} \mu \mathrm{g} \mathrm{kg}^{-1} \mathrm{~d}^{-1}$ and $4.82 \times 10^{-16} \mu \mathrm{g} \mathrm{kg}^{-1} \mathrm{~d}^{-1}$ to $80.70 \times 10^{-16} \mu \mathrm{g} \mathrm{kg}^{-1} \mathrm{~d}^{-1}$ with a mean of $40.90 \times 10^{-16} \mu \mathrm{g} \mathrm{kg}^{-1} \mathrm{~d}^{-1}$ respectively.. Radiological hazard indicator of radium is of concern in these drinking river water samples.
\end{abstract}

Keywords: Activity concentration; Radiological hazard; River water; Age-dependent effective dose; Lifetime cancer risk; Toxicity risks. 


\section{Introduction}

Natural radioactivity in water has been attracting widespread attention because of the health problems that radioactive materials cause when they enter the human body through drinking water. Naturally occurring radionuclides such as uranium, thorium, radium and their decay products in drinking water give rise to radiation exposure through the drinking water pathway. It has been reported that the average worldwide radiation exposure to natural sources in foods and drinking water is $0.29 \mathrm{mSv} \mathrm{y}^{-1}$, made up of about $0.17 \mathrm{mSv} \mathrm{y}^{-1}$ from ${ }^{40} \mathrm{~K}$ and about $0.12 \mathrm{mSv} \mathrm{y}^{-1}$ from uranium and thorium [1]. The World Health Organization (WHO) has recommended safe values for various drinking water quality parameters in its general guidelines [2], which has been used by many countries to formulate their own national water quality guidelines.

Radium is regarded as a highly toxic element in water. It exists in four naturally occurring isotopes ${ }^{223} \mathrm{Ra}^{224} \mathrm{Ra},{ }^{226} \mathrm{Ra}$ and ${ }^{228} \mathrm{Ra}$. Many studies have been conducted on the occurrence and levels of ${ }^{224} \mathrm{Ra},{ }^{226} \mathrm{Ra}$ and ${ }^{228} \mathrm{Ra}$ in drinking water [3-9]. While radium- 223 is a decay product of ${ }^{235} \mathrm{U}$ ( a rare uranium isotope), ${ }^{224} \mathrm{Ra}$ and ${ }^{228} \mathrm{Ra}$ originate from the decay of ${ }^{232} \mathrm{Th}$. Radium -226 is a decay product of ${ }^{238} \mathrm{U}$. Whereas both ${ }^{223} \mathrm{Ra}$ and ${ }^{224} \mathrm{Ra}$ are very short-lived radium isotopes with half live of 11.4 days and 3.6 days respectively, ${ }^{226} \mathrm{Ra}$ and ${ }^{228} \mathrm{Ra}$ are more stable with half-lives of 1602 years and 5.75 years respectively and hence the predominant radium isotopes in groundwater. When disintegrating, these radium isotopes emit nuclear radiations that can penetrate and ionize matter to various levels. Although ${ }^{224} \mathrm{Ra}$ and ${ }^{226} \mathrm{Ra}$ essentially emit $\alpha$-radiation, which is believed to be the cause of prevailing deleterious health effects or tissue damage $[3,10] .{ }^{228}$ Ra emits $\beta$-radiation. Radium also releases some $\gamma$-radiation. Radium enters surface and groundwater systems through processes such as aquifer solid weathering, direct recoil over the liquid-solid limit, desorption from the sediment surfaces, etc. The movement of radium in water is dependent on the geochemical 
properties of solids in the aquifer. Its activity concentration in groundwater depends on its activity concentration in the bedrock, mechanisms like precipitation, dissolution, complexation and adsorption-desorption, which affects its transport in water. All the processes are related to the chemical composition of groundwater [11]

Due to its similar metabolism to calcium, ${ }^{226} \mathrm{Ra}$ is a bone-seeker. Hence it is in the skeleton that the animal ingesting ${ }^{226} \mathrm{Ra}$ would have the greatest body burden. After ingestion, about 80 to $85 \%$ of radium is promptly expelled from the body through faeces while the rest 15 to $20 \%$ enters the blood stream and is transported to all parts of the body and is deposited on bone surfaces [8]. The radium deposits on bone surfaces are eventually covered by new deposits and old deposits penetrate deeper into the bone, where it builds up in growing bones and remains in the skeleton for a long time where it can cause bone cancer. Exposure to higher levels of radium than the Maximum Contaminant Level (MCL) over a long period of time may also result in other harmful effects like anaemia, cataracts, fractured teeth, acute leucopenia, necrosis of the jaw cancers (other than bone cancer) and even death. The adverse effect depends on its amount in water (dose), quantity of water consumed, how long an individual is exposed to it (duration) and individual characteristics such as age, state of health, lifestyle etc.

The U.S. Environmental Protection Agency [12] has established MCL of $0.185 \mathrm{~Bq}^{-1}$ for combined radium $\left({ }^{226} \mathrm{Ra}\right.$ plus $\left.{ }^{228} \mathrm{Ra}\right)$ for drinking water whereas the MCL fixed by the World Health Organization [14] is $1.0 \mathrm{~Bq}^{-1}$ and $0.1 \mathrm{~Bq} \mathrm{l}^{-1}$ for ${ }^{226} \mathrm{Ra}$ and ${ }^{228} \mathrm{Ra}$ respectively. Health Canada's [15] MCL for ${ }^{226} \mathrm{Ra}$ only is $0.5 \mathrm{~Bq}^{-1}$.

Since there is no adequate supply of pipe borne or potable water in many rural communities in Nigeria, people of those communities turn to dug wells, rivers and streams (surface waters) as sources of drinking water. No water treatment plant or local water purification system is available for treating their drinking water in these rural areas to reduce 
or remove the microbial or radioactivity load. River water is used for direct drinking and other purposes without filtering by the local population. The area chosen for this study, with a population of about 510,700, is one of such rural areas in southwestern Nigeria. So, it is necessary to determine the activity concentrations of natural radionuclides in water of these rivers and quantitate radium in the drinking water in order to measure its dose and risk to the target demographic group. Maxwell et al. [9] reported a range of 0.44 to $2.7 \mathrm{mBq}^{-1}{ }^{226} \mathrm{Ra}$ activity concentration in groundwater-based drinking water samples in Dawaki,Kuje, Giri and Sabon-Lugbe area of Abuja, North Cental Nigeria. Adekoya [15] reported a range of 1.62 to 3.17 $\mathrm{Bq} \mathrm{l}^{-1} 226 \mathrm{Ra}$ activity concentrations in potable drinking water samples from former tinmining areas with elevated activity in Jos, Nigeria. Agaja and Ajisafe [16] reported a range of 0.5 to $5.6 \mathrm{~Bq}^{-1}{ }^{226} \mathrm{Ra}$ activity concentrations in borehole and surface (river) drinking water samples on coastal communities of Delta state, Nigeria. In a similar investigation carried out in Tanke, Ilorin, Nigeria, Nwakwo [17] reported 226Ra activity concentration ranging from 0.8 to $7.4 \mathrm{~Bq}^{-1}$ Available literatures on this subject shows that activity concentration of ${ }^{226} \mathrm{Ra}$ and ${ }^{228} \mathrm{Ra}$ in drinking water has not been determined in any part of the Bitumen belt of Ondo State, Nigeria. This study was aimed at determining the natural radionuclides content of water of some selected rivers in Okitipupa and Irele areas of Ondo State, southwestern Nigeria as well as the mass concentration of ${ }^{226} \mathrm{Ra}$ and ${ }^{228} \mathrm{Ra}$, and assessing the radiological implications of human exposure to ionizing radiation emitted by these radionuclides.

\section{Study Area}

Ondo State lies between longitude $4^{\circ} 30^{\prime} \mathrm{E}$ and $6^{\circ} 0^{\prime} \mathrm{E}$ and latitude $6^{\circ} 0^{\prime} \mathrm{N}$ and $7^{\circ} 30^{\prime} \mathrm{N}$ with mean annual rainfall of $1,150 \mathrm{~mm}$ in the northern areas to about $2,000 \mathrm{~mm}$ in the southern areas; relative humidity between $70 \%$ and $85 \%$ in the southern part and less than $78 \%$ in the northern part, with mean temperature of $21^{\circ} \mathrm{C}$ in the south and $32^{\circ} \mathrm{C}$ in the north [18]. 
Okitipupa and Irele Local Government Areas fall within the bitumen belt of Ondo State and are predominantly populated by the Ikales of Yoruba extraction. Rivers in the area include; Ominla, Akeun, Ufara, Otu, Oha and Oni, and the vast River Oluwa. The waters of these rivers serve as a major source of drinking water and livelihood to the people of this region, since fishing is their main occupation. The people also use the waters for drinking, bathing, washing and other domestic purposes without using any water treatment methods to remove radioactivity. Bottom river sediments are also dug and used in building construction in the region.

\section{Methods}

\section{Sample collection and preparation}

In this study, river water samples were taken along the course of five major rivers; Akeun, Oha, Oluwa, Otu and Ufara in Irele and Okitipupa Local Government Areas of Ondo State, Southwestern Nigeria. Ten water samples were taken from the rivers, two samples per river.

The water samples were transferred into 1 litre polyethylene gallons with $1 \mathrm{ml}$ of dilute hydrochloric acid added to it in order to prevent adherence of the radionuclides to the walls of the containers. Each water (with a volume of 1 litre) sample was placed in a Marinelli beaker. The Marinelli beakers were properly sealed with polyvinyl chloride (PVC) tapes to prevent escape of ${ }^{222} \mathrm{Rn}$ and ${ }^{220} \mathrm{Rn}$ from the samples. The samples in the Marinelli beakers were stored for four weeks to allow time for ${ }^{222} \mathrm{Rn}$ to attain a state of secular equilibrium with its short-lived decay products prior to gamma spectroscopy. After these, the samples were taken to the Ghana Atomic Energy Commission (G.A.E.C), Legon, Accra, Ghana for analysis with the hihg-purity germanium (HpGe) detector.

\section{Sample Analysis}


The activity concentrations of the samples were measured by using a computerized gamma ray spectrometry system consisting of a high purity germanium (HPGe) detector of $40 \%$ relative efficiency coupled to conventional electronics, which was connected to a multichannel cnalyzer card (MCA) set up on a desktop. The resolution of the spectrometer was $1.8 \mathrm{keV}$ for $1.33 \mathrm{MeV}$ line of ${ }^{60} \mathrm{Co}$. A user-friendly MAESTRO-30 spectra analyzer software was used to store and analyze the data, and evaluated the radionuclide activity concentrations in the water samples. The spectrometer was placed at the centre of a $5-\mathrm{cm}$ thick cylindrical lead shield, which was lined with layers of 3-mm thick copper, Plexiglass and cadmium to reduce the background gamma-ray. A mixed calibration standard serial number NW 146 in form of solid water from Deutscher Kalibrierdienst (DKD-3) QSA Global GmBH, Germany was used for energy and efficiency calibrations of the detector in the same geometry as the samples. To acquire spectral for each sample, counting was done for 36,000 s. The gamma-ray emissions of ${ }^{214} \mathrm{~Pb}(351.9 \mathrm{keV})$ and ${ }^{214} \mathrm{Bi}(609.3 \mathrm{keV}$ and $1120.3 \mathrm{keV})$ were used to estimate the activity concentrations of ${ }^{226} \mathrm{Ra}$, for determination of activity concentrations of ${ }^{228} \mathrm{Ra}$, gamma-ray peaks of ${ }^{228} \mathrm{Ac}(911 . \mathrm{keV})$ and ${ }^{208} \mathrm{Tl}(583 \mathrm{keV}$ and 2615 $\mathrm{keV}$ ) were used. The activity concentrations of ${ }^{40} \mathrm{~K}$ were evaluated using its single emission line situated at $1460.8 \mathrm{keV}$.

The activity concentrations ( $\mathrm{A}_{\mathrm{sp}}$ ) of ${ }^{226} \mathrm{Ra},{ }^{228} \mathrm{Ra}$ and ${ }^{40} \mathrm{~K}$ in $\mathrm{Bq} \mathrm{kg}^{-1}$ for the water and sediment samples were determined using the expression [19]

$$
\mathrm{A}_{\mathrm{ac}}=\frac{\mathrm{C}_{\mathrm{sam}}}{\mathrm{P}_{\varepsilon} \cdot \mathrm{E} C_{T} \mathrm{~V}}
$$

where, $\mathrm{C}_{\mathrm{sam}}$ is the final count of the radionuclide in a sample, $\mathrm{P}_{\varepsilon}$ is the emission probability, $\mathrm{E}$ is the efficiency of the detector, $\mathrm{C}_{\mathrm{T}}$ is the counting time, $\mathrm{V}$ is the volume of sample.

\section{Calculation of Mass Concentration of ${ }^{226} \mathbf{R a}$ and ${ }^{228} \mathbf{R a}$}

The mass concentrations of ${ }^{226} \mathrm{Ra}$ and ${ }^{228} \mathrm{Ra}$ in the water samples were calculated from their activity concentrations using 


$$
A_{B q}=\frac{M}{M_{R a}} N_{A} \frac{\ln 2}{t_{1 / 2}}
$$

which yields

$$
M=\frac{A_{B q}}{N_{A}} \frac{M_{R a} t_{1 / 2}}{\ln 2}
$$

where $\mathrm{A}_{\mathrm{Bq}}$ is the activity of ${ }^{226} \mathrm{Ra}$ or ${ }^{228} \mathrm{Ra}(\mathrm{Bq}), \mathrm{M}_{\mathrm{Ra}}$ is the atomic mass of ${ }^{226} \mathrm{Ra}$ or ${ }^{228} \mathrm{Ra}(\mathrm{g}$ $\left.\mathrm{mol}^{-1}\right), \mathrm{N}_{\mathrm{A}}$ is Avogadro constant $\left(6.022 \times 10^{23} \mathrm{~mol}^{-1}\right)$, and $\mathrm{t}_{1 / 2}$ is the half-life of ${ }^{226} \mathrm{Ra}$ or ${ }^{228} \mathrm{Ra}$ (1602 y and 5.75 y respectively

\section{Annual effective dose rates of the river water samples}

The annual effective dose from ingestion of radionuclides in the water samples was estimated on the basis of the activity concentrations of the radionuclides, the volume of the water intake, which depends on the age of the person taking the water, and the age-dependent dose conversion factors for the radionuclides. The annual effective dose due to water intake was calculated using the equation [1]

$$
\mathrm{E}_{\mathrm{d}}=\mathrm{A}_{\mathrm{c}} \mathrm{A}_{\mathrm{I}} \mathrm{C}_{\mathrm{f}}
$$

The total annual effective dose $\mathrm{D}\left(\mathrm{mSv} \mathrm{y}^{-1}\right)$ to an individual was established by summing contributions from all radionuclides present in the water samples i.e.

$$
\mathrm{D}=\sum_{\mathrm{i}}\left(\mathrm{Ac}_{\mathrm{c}}\right)_{\mathrm{i}} \mathrm{Al}_{\mathrm{I}}\left(\mathrm{C}_{\mathrm{f}}\right)_{\mathrm{i}}
$$

where $\mathrm{i}$ are the radionuclides ${ }^{226} \mathrm{Ra}$, and ${ }^{228} \mathrm{Ra}, \mathrm{A}_{c}$ is the activity concentration of the radionuclide in the water $\left(\mathrm{Bq} \mathrm{l}^{-1}\right), \mathrm{A}_{\mathrm{i}}$ is the annual intake of the drinking water $\left(\mathrm{y} \mathrm{y}^{-1}\right)$ and $\mathrm{C}_{\mathrm{f}}$ is the ingested dose conversion factor for ${ }^{226} \mathrm{Ra}$ and ${ }^{228} \mathrm{Ra}\left(\mathrm{Sv} \mathrm{Bq}{ }^{-1}\right)$, which varies with both radionuclides under consideration and the age of individuals ingesting the radionuclides.

The intake rates and conversion factors used in this study were based on the International Commission on Radiological Protection [20] for age groups 0-1 y, 1-2 y, 2-7 y, 7-12 y, 12-17 y, and >17 y old with annual average water intake estimated as 200, 260, 300, 350, 600 and 730 litres respectively. 
The dose conversion factors for ingestion of natural radionuclides for members of the public, according to the ICRP are different with respect to different age groups. Table 1 shows the various dose conversion factors for different age groups for the natural radionuclides $\left({ }^{226} \mathrm{Ra}\right.$ and $\left.{ }^{228} \mathrm{Ra}\right)$ in the water samples analyzed.

Table 1 Dose conversion factors $\left(\mathrm{Sv} \mathrm{Bq}^{-1}\right)$ for ingested natural radionuclides for the general public ${ }^{(20)}$.

\begin{tabular}{|c|c|c|c|c|c|c|}
\hline Radionuclide & $\leq 1$ year & $1-2$ years & $2-7$ years & $7-12$ years & $\begin{array}{c}12-17 \\
\text { years }\end{array}$ & $\begin{array}{c}\text { Above } 17 \\
\text { years }\end{array}$ \\
\hline Ra-226 & $4.7 \mathrm{E}-6$ & $9.6 \mathrm{E}-7$ & $6.2 \mathrm{E}-7$ & $8.0 \mathrm{E}-7$ & $1.5 \mathrm{E}-6$ & $2.8 \mathrm{E}-7$ \\
\hline Ra-228 & $3.0 \mathrm{E}-5$ & $5.7 \mathrm{E}-6$ & $3.4 \mathrm{E}-6$ & $3.9 \mathrm{E}-6$ & $5.3 \mathrm{E}-6$ & $6.9 \mathrm{E}-7$ \\
\hline
\end{tabular}

\section{Toxicity Radiological risk assessment of radium in the water samples.}

To assess the health hazards due to the ingestion of radium in the water samples in this study, two types of radium toxicity were evaluated - radiological toxicity due to ${ }^{226} \mathrm{Ra}$ and ${ }^{228} \mathrm{Ra}$ as emitters of high ionizing power radiations and chemical toxicity due to their being a heavy elements.

\section{Radiological toxicity assessment}

The radiological toxicity of radium was estimated as the life time cancer risk (LTCR) due to ingestion of radium in the water samples using [21,22].

$\mathrm{LTCR}=\mathrm{A}_{c} \mathrm{C}_{c} \mathrm{~V}_{\mathrm{c}} \mathrm{Le}_{\mathrm{e}}$

where $A_{c}$ is activity concentration of radium $\left({ }^{226} \mathrm{Ra}\right.$, and $\left.{ }^{228} \mathrm{Ra}\right)$ in drinking water sample, $\mathrm{C}_{\mathrm{c}}$ is Cancer risk coefficient, $\mathrm{V}_{\mathrm{c}}$ is Volume of water consumed and $\mathrm{L}_{\mathrm{e}}$ is Life expectancy.

Cancer risk coefficients of $7.17 \times 10^{-9}$ and $1.04 \times 10^{-8} \mathrm{~Bq}^{-1}$ of ${ }^{226} \mathrm{Ra}$, and $2.00 \times 10^{-8}$ and $2.81 \times 10^{-8}$ of ${ }^{228} \mathrm{Ra}$ for mortality and morbidity respectively were taken from EPA [23] and UNSCEAR [1]. The average Nigerian life expectancy at birth is $45.5 \mathrm{y}$, that is about 16,619 days for both males and females [1] and average adult daily consumption of water is about 21 [13]. 


\section{Chemical Toxicity Assessment}

The chemical toxicity (non-carcinogenic) risk due to ingestion of radium in the water samples was assessed in terms of the Lifetime Average Daily Dose (LADD). LADD is expressed as the quantity of the toxic substance taken into the body per kilogram of body mass per day. It was calculated using $[14,21,24,25]$

$$
L A D D=\frac{C \times I R x E D x E F}{B W x A T \times 365}
$$

where $\mathrm{C}$ is the mass concentration of ${ }^{226} \mathrm{Ra}$ or ${ }^{228} \mathrm{Ra}\left(\mu \mathrm{g} \mathrm{l}{ }^{-1}\right)$, IR is water consumption rate (1 day $\left.^{-1}\right), \mathrm{ED}$ is total exposure duration (y), EF is exposure frequency (days $\mathrm{y}^{-1}$ ), BW is average body mass of consumer $(\mathrm{kg})$ and AT is average time, which is the life expectancy (y). The water consumption rate was set at 21 day $^{-1}$. The total exposure frequency was 365.25 days and total exposure duration was 45.5 y (about 16,619 days ) and average man's mass of $70 \mathrm{~kg}$ was used for the calculation of LADD.

\section{Hazard quotient}

Hazard quotient of a toxic material is a measure of he extent of damage done as a result of the ingestion of the material. In this context, the materials are ${ }^{226} \mathrm{Ra}$ and ${ }^{228} \mathrm{Ra}$ ingested in the investigated drinking water samples. Hazard Quotient (HQ) was calculated using [22,26,27]

$$
H Q=\frac{L A D D}{R_{f} D}
$$

where LADD is the Lifetime Average Daily Dose and $\mathrm{R}_{\mathrm{f}} \mathrm{D}$ is reference dose, equal $1.12 \mu \mathrm{g}$ $\mathrm{kg}^{-1}$ day $^{-1}[13]$

\section{Results and discussion}

Activity concentrations of natural radionuclides in river water samples.

Measured activity concentrations of ${ }^{226} \mathrm{Ra},{ }^{228} \mathrm{Ra}$ and ${ }^{40} \mathrm{~K}$ in water samples of the rivers and the total annual effective dose for the six ICRP age groups 0-1 y, 1-2 y, 2-7 y, 7-12 y, 12-17 y 
and $>17 \mathrm{y}$ are displayed in Table 2 . The activity concentrations of ${ }^{226} \mathrm{Ra}$ varied from $0.12 \pm 0.02 \mathrm{~Bq} \mathrm{l}^{-1}$ in Oluwa river water sample (Opa) to $2.31 \pm 0.35 \mathrm{~Bq} \mathrm{l}^{-1}$ in Akeun river water 
Table 2 Activity concentrations of radionuclides in the water samples and total annual effective dose to different age groups

\begin{tabular}{|c|c|c|c|c|c|c|c|c|c|c|}
\hline \multirow[t]{2}{*}{ River } & \multirow[t]{2}{*}{ Sample location } & \multicolumn{3}{|c|}{ Activity concentration $\left(\mathrm{Bq}^{-1}\right)$} & \multicolumn{6}{|c|}{ Total annual effective dose $\left(\mathrm{mSv}^{-1}\right)$} \\
\hline & & ${ }^{226} \mathrm{Ra}$ & ${ }^{228} \mathrm{Ra}$ & ${ }^{40} \mathrm{~K}$ & $0-1 \mathrm{y}$ & $1-2 y$ & $2-7 \mathrm{y}$ & $7-12 y$ & $12-17$ y & $>17 \mathrm{y}$ \\
\hline \multirow[t]{2}{*}{ Oluwa } & Opa & $0.12 \pm 0.02$ & $0.17 \pm 0.03$ & $7.86 \pm 1.18$ & 1.13 & 0.28 & 0.20 & 0.27 & 0.65 & 0.11 \\
\hline & Araromi Ayeka & $0.58 \pm 0.08$ & $0.52 \pm 0.08$ & $21.34 \pm 3.20$ & 3.67 & 0.92 & 0.64 & 0.87 & 2.18 & 0.38 \\
\hline \multirow[t]{2}{*}{ Akeun } & Ikoya 1 & $2.31 \pm 0.35$ & $1.78 \pm 0.27$ & $52.76 \pm 7.91$ & 12.85 & 3.22 & 2.25 & 3.08 & 7.74 & 1.37 \\
\hline & Ikoya 2 & $1.77 \pm 0.33$ & $2.77 \pm 0.61$ & $65.51 \pm 2.43$ & 18.28 & 4.55 & 3.16 & 4.28 & 10.4 & 1.76 \\
\hline \multirow[t]{2}{*}{ Ufara } & Oloto 1 & $0.82 \pm 0.34$ & $2.29 \pm 0.79$ & $56.38 \pm 1.60$ & 14.51 & 3.60 & 2.49 & 3.36 & 8.02 & 1.32 \\
\hline & Oloto 2 & $2.18 \pm 0.60$ & $2.85 \pm 0.47$ & $64.90 \pm 1.27$ & 19.15 & 4.77 & 3.31 & 4.50 & 11.03 & 1.88 \\
\hline \multirow[t]{2}{*}{ Oha } & Akotogbo 1 & $2.03 \pm 0.30$ & $1.25 \pm 0.19$ & $7.95 \pm 1.19$ & 9.41 & 2.36 & 1.65 & 2.28 & 5.80 & 1.05 \\
\hline & Akotogbo 2 & $0.58 \pm 0.09$ & $0.44 \pm 0.07$ & $10.91 \pm 1.64$ & 3.19 & 0.80 & 0.56 & 0.76 & 1.92 & 0.34 \\
\hline \multirow[t]{2}{*}{ Otu } & Iyara 1 & $1.09 \pm 0.16$ & $1.22 \pm 0.18$ & $21.81 \pm 3.27$ & 8.35 & 2.08 & 1.45 & 1.97 & 4.86 & 0.84 \\
\hline & Iyara 2 & $1.31 \pm 0.20$ & $1.14 \pm 0.17$ & $14.26 \pm 2.14$ & 8.07 & 1.94 & 1.41 & 1.92 & 4.81 & 0.84 \\
\hline Minimum & & 0.12 & 0.17 & 7.86 & 1.13 & 0.28 & 0.20 & 0.27 & 0.65 & 0.11 \\
\hline Maximum & & 2.31 & 2.85 & 65.51 & 19.15 & 4.77 & 3.31 & 4.50 & 11.03 & 1.88 \\
\hline Mean & & 1.23 & 1.44 & 32.37 & 9.86 & 2.46 & 1.71 & 2.43 & 5.74 & 0.99 \\
\hline $\begin{array}{l}\text { Standard } \\
\text { Deviation }\end{array}$ & & 0.76 & 0.96 & 24.42 & 6.26 & 1.56 & 1.08 & 1.46 & 3.56 & 0.60 \\
\hline
\end{tabular}

( \pm represents counting error) 
sample (Ikoya 1) with a mean ( \pm standard deviation $(\mathrm{SD})$ ) of $1.23 \pm 0.76 \mathrm{~Bq} \mathrm{l}^{-1}$. Radium-228 activity concentration varied from $0.17 \pm 0.03 \mathrm{~Bq}^{-1}$ in Oluwa river water sample (Opa) to $2.85 \pm 0.47 \mathrm{~Bq} \mathrm{l}^{-1}$ in Ufara river water sample (Oloto 2$)$ with a mean $( \pm \mathrm{SD})$ value of $1.44 \pm 0.96$ $\mathrm{Bq}^{-1}$. That of ${ }^{40} \mathrm{~K}$ ranged from $7.86 \pm 1.18 \mathrm{~Bq} \mathrm{l}^{-1}$ in Oluwa river water sample (Opa) to $65.51 \pm 2.43 \mathrm{~Bq} \mathrm{l}^{-1}$ in Akeun river water sample (Ikoya 2$)$ with a mean $( \pm \mathrm{SD})$ value of $32.37 \pm 24.42 \mathrm{~Bq} \mathrm{l}^{-1}$. In $50 \%$ of the water samples, activity concentration of radionuclides is of the order ${ }^{226} \mathrm{Ra}<{ }^{228} \mathrm{Ra}<{ }^{40} \mathrm{~K}$ while in the remaining $50 \%$, it is of order ${ }^{228} \mathrm{Ra}<{ }^{238} \mathrm{U}<{ }^{40} \mathrm{~K}$. River Oluwa water sample (Opa) exhibits the minimum activity concentration for all the natural radionuclides while river Akeun water sample (Ikoya 1) exhibits the maximum activity concentration for ${ }^{226} \mathrm{Ra},{ }^{228} \mathrm{Ra}$ maximum activity concentration was exhibited by Ufara river water sample (Oloto 2) and river Akeun water sample (Ikoya 2) presents the maximum activity concentration of $65.51 \mathrm{~Bq}^{\mathrm{l}^{-1}}$ for ${ }^{40} \mathrm{~K}$.

Table 3 displays the minimum, maximum and mean $( \pm \mathrm{SD})$ of the activity concentrations of the radionuclides for the 5 rivers. 
Table 3 Minimum, maximum and mean activity concentrations of ${ }^{226} \mathrm{Ra},{ }^{228} \mathrm{Ra}$ and ${ }^{40} \mathrm{~K}$ in the river water samples

\begin{tabular}{|c|c|c|c|c|}
\hline \multirow[t]{2}{*}{ River } & \multirow[t]{2}{*}{ Statistics } & \multicolumn{3}{|c|}{ Activity concentration $\left(\mathrm{Bq} \mathrm{l}^{-1}\right)$} \\
\hline & & ${ }^{226} \mathrm{Ra}$ & ${ }^{228} \mathrm{Ra}$ & ${ }^{40} \mathrm{~K}$ \\
\hline \multirow[t]{5}{*}{ Oluwa } & Minimum & 0.12 & 0.17 & 7.86 \\
\hline & Maximum & 0.58 & 0.52 & 21.34 \\
\hline & Mean & 0.35 & 0.35 & 14.60 \\
\hline & Standard Deviation & 0.23 & 0.18 & 6.74 \\
\hline & Standard Error & 0.16 & 0.12 & 4.77 \\
\hline \multirow[t]{5}{*}{ Akeun } & Minimum & 1.77 & 1.78 & 52.76 \\
\hline & Maximum & 2.31 & 2.77 & 65.51 \\
\hline & Mean & 2.04 & 2.28 & 59.14 \\
\hline & Standard Deviation & 0.27 & 0.50 & 6.38 \\
\hline & Standard Error & 0.19 & 0.35 & 4.51 \\
\hline \multirow[t]{5}{*}{ Ufara } & Minimum & 0.82 & 2.29 & 56.38 \\
\hline & Maximum & 2.18 & 2.85 & 64.90 \\
\hline & Mean & 1.50 & 2.57 & 60.64 \\
\hline & Standard Deviation & 0.68 & 0.28 & 4.26 \\
\hline & Standard Error & 0.48 & 0.20 & 3.01 \\
\hline \multirow[t]{5}{*}{ Oha } & Minimum & 0.58 & 0.44 & 7.95 \\
\hline & Maximum & 2.03 & 1.25 & 10.91 \\
\hline & Mean & 1.31 & 0.85 & 9.43 \\
\hline & Standard Deviation & 0.73 & 0.41 & 1.48 \\
\hline & Standard Error & 0.51 & 0.29 & 1.05 \\
\hline \multirow[t]{5}{*}{ Otu } & Minimum & 1.09 & 1.14 & 14.26 \\
\hline & Maximum & 1.31 & 1.22 & 21.81 \\
\hline & Mean & 1.20 & 1.18 & 18.04 \\
\hline & Standard Deviation & 0.11 & 0.04 & 3.78 \\
\hline & Standard Error & 0.08 & 0.03 & 2.67 \\
\hline
\end{tabular}

River Akeun gave the highest mean activity concentration for ${ }^{226} \mathrm{Ra}\left(2.04 \mathrm{~Bq} \mathrm{l}^{-1}\right)$ while River Oluwa exhibits its lowest activity concentration $\left(0.35 \mathrm{~Bq}^{-1}\right)$. The highest mean activity concentration for ${ }^{228} \mathrm{Ra}\left(2.50 \mathrm{~Bq}^{-1}\right)$ was found in River Ufara while River Oluwa showed its lowest activity concentration $\left(0.35 \mathrm{~Bq}^{-1}\right)$.

The calculated total annual effective doses for all river water samples varied from 1.13 to $19.15 \mathrm{mSv} \mathrm{y}^{-1}$. for age group $0-1 \mathrm{y}, 0.28$ to $4.77 \mathrm{mSv}^{-1}$ for $1-2 \mathrm{y}$ age group, 0.20 to 3.31 $\mathrm{mSv}^{-1}$ for age group $2-7 \mathrm{y}, 0.27$ to $4.50 \mathrm{mSv}^{-1}$ for $7-12 \mathrm{y}$ age group, 0.65 to 11.03 
$\mathrm{mSv} \mathrm{y}^{-1}$ for age group $12-17 \mathrm{y}$ and 0.11 to $1.88 \mathrm{mSv}^{-1}$ for age group $>17 \mathrm{y}$, with mean values of $9.86,2.46,1.71,2.43,5.74$ and $0.99 \mathrm{mSv} \mathrm{y}^{-1}$ respectively. The mean values show that infants in the age group from birth to $1 \mathrm{y}$ receive highest radiation dose than all other age groups. These values are higher than recommended reference levels of $0.26,0.20$ and 0.1 $\mathrm{mSv} \mathrm{y}^{-1}$ for infants $(0-1 \mathrm{y}$ and $1-2 \mathrm{y}$ age groups), children $(2-7 \mathrm{y}$ and $7-12 \mathrm{y}$ age groups ) and adults (12 - $17 \mathrm{y}$ and $>17 \mathrm{y}$ age groups) respectively by the World Health Organization [27], International Atomic Energy Agency [28] and the United Nations Scientific Committee on Effects of Atomic Radiation [1]. The variations of total annual effective dose values to different age groups are shown in Fig. 1 


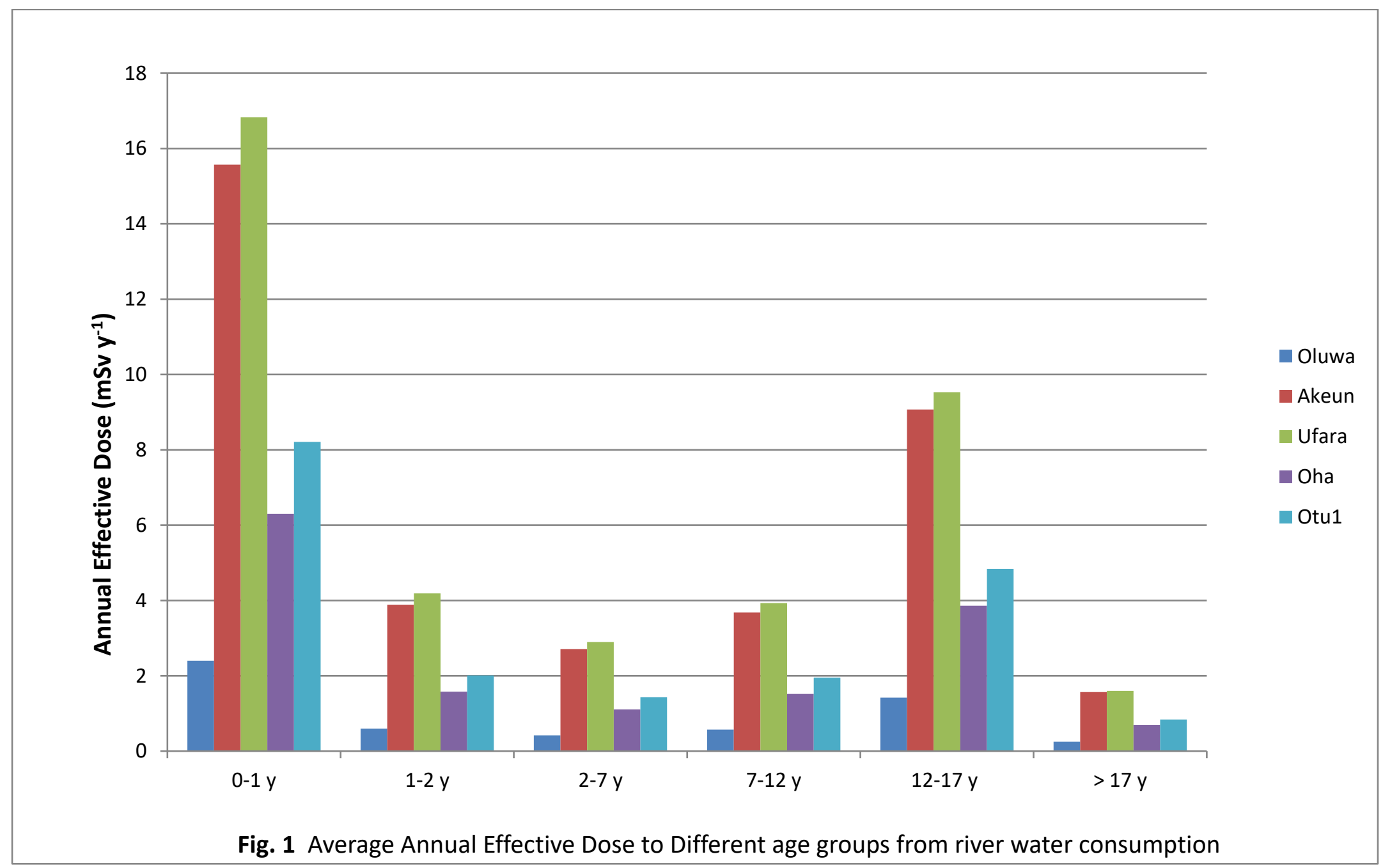


All the river water samples show annual effective doses that exceed the World Health Organization safe limit of $0.1 \mathrm{mSv} \mathrm{y}^{-1}$ from drinking water for all age groups $[13,28]$ except river Oluwa water for age groups $1-2,2-7 \mathrm{y}, 7-12 \mathrm{y}$ and $>17 \mathrm{y}$. All samples cross the safe limit of annual effective dose of $1.0 \mathrm{mSv}^{-1}$ set by the International Commission on Radiological Protection [29]. Water samples from River Ufara present the highest radiation doses to all age groups while River Oluwa water samples impart the least radiation dose from all radionuclides investigated. The variations of total annual effective dose values in the different rivers are shown in Fig. 2. 


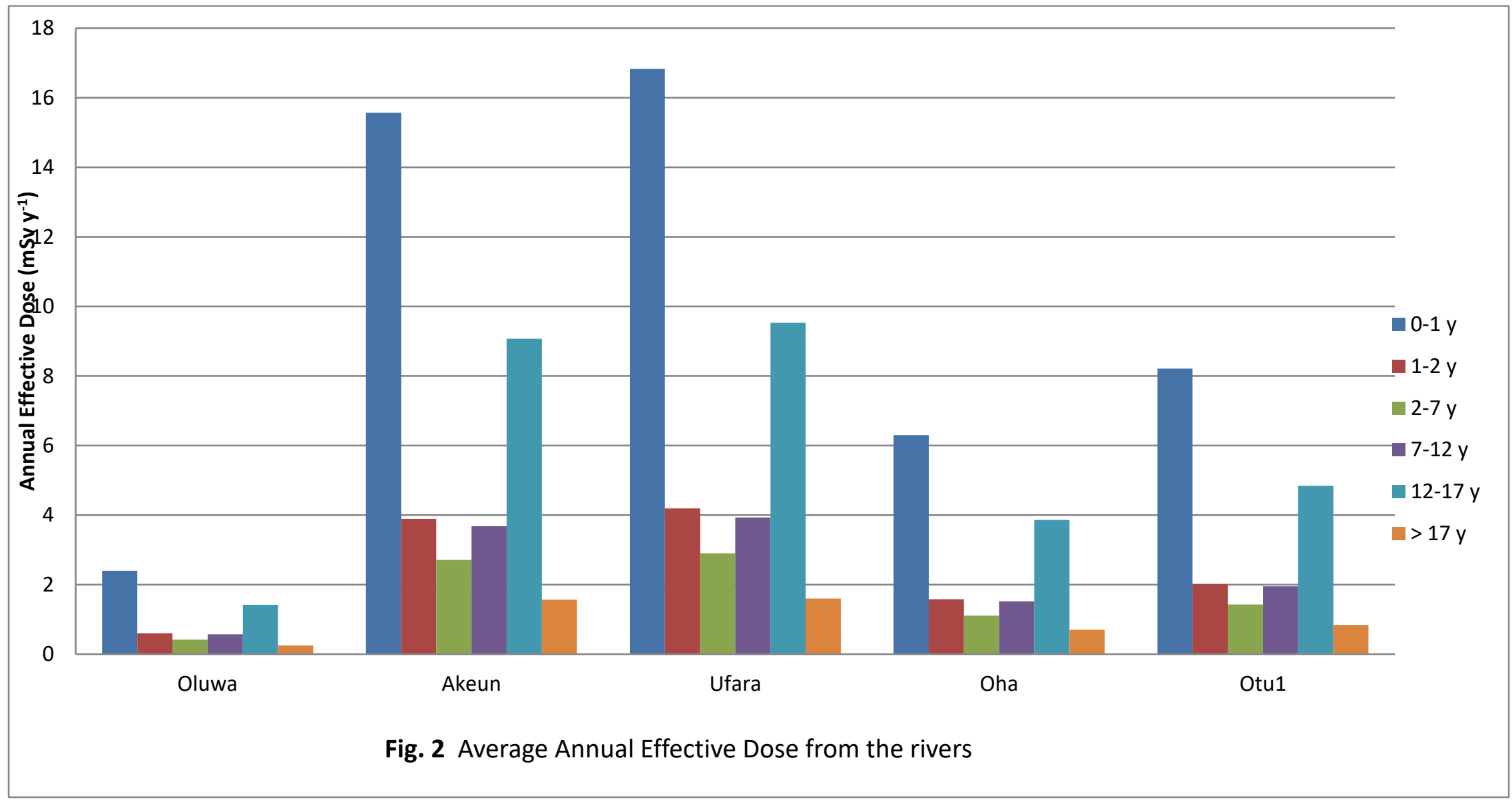


The total annual effective doses from various drinking water sources including groundwater, dug well, surface (river) water, sachet, bottled, etc. have been determined at different locations. Annual effective dose values higher than permissible limit in drinking water have been found in some parts of southwestern Nigeria. Achuka et al. [30] reported 5.21 to 14.26 $\mathrm{mS} \mathrm{y}{ }^{-1}, 5.36-14.25 \mathrm{mSv} \mathrm{y}^{-1}, 3.85$ to $10.22 \mathrm{mSv} \mathrm{y}^{-1}, 3.82$ to $10.13 \mathrm{mSv} \mathrm{y}^{-1}, 6.34-16.77 \mathrm{mSv}$ $\mathrm{y}^{-1}$ and 3.31 to $8.75 \mathrm{mSv} \mathrm{y}^{-1}$ with a mean value of $9.58,9.58,6.87,6.86,11.91$ and $5.86 \mathrm{mSv}$ $\mathrm{y}^{-1}$ for age groups $0-1 \mathrm{y}, 1-2 \mathrm{y}, 2-7 \mathrm{y}, 7-12 \mathrm{y}, 12-17 \mathrm{y}$ and $>17 \mathrm{y}$ respectively in drinking water samples in Ogun State. Similarly Ajayi and Adesida [31] reported annual effective doses in the range 4.73 to $49.13 \mathrm{mSv} \mathrm{y}^{-1}, 1.21$ to $12.26 \mathrm{mSv}^{-1}, 0.86$ to $8.54 \mathrm{mSv}^{-}$ 1, 1.22 to $11.66 \mathrm{mSv} \mathrm{y}^{-1}, 3.40$ to $28.98 \mathrm{mSv}^{-1}$ and 0.68 to $5.04 \mathrm{mSv} \mathrm{y}^{-1}$ with mean values of $19.14,4.87,3.46,4.89,13.36$ and $2.61 \mathrm{mSv} \mathrm{y}^{-1}$ for age group $0-1 \mathrm{y}, 1-2 \mathrm{y}, 2-7 \mathrm{y}, 7-12$ $\mathrm{y}, 12-17 \mathrm{y}$ and $>17 \mathrm{y}$ respectively in some sachet drinking water samples produced in Nigeria.

In like manner, Ajayi and Owolabi [32] reported annual effective doses in the range 0.05 to $481.60 \mathrm{mSv} \mathrm{y}^{-1}, 0.02$ to $76.84 \mathrm{mSv} \mathrm{y}^{-1}$ and 0.01 to $35.80 \mathrm{mSv} \mathrm{y}^{-1}$ for age groups $<1 \mathrm{y}, 2-7 \mathrm{y}$ and $>17$ y respectively in drinking water from private dug wells in Akure. Nigeria. Also Ajayi and Achuka [33] reported annual effective doses in the range 0.04 to $6.82 \mathrm{mSv} \mathrm{y}^{-1}, 0.01$ to $1.36 \mathrm{mSv}^{-1}$ and 0.01 to $1.49 \mathrm{mSv}^{-1}$ for age groups $<1 \mathrm{y}, 2-7 \mathrm{y}$ and $>17 \mathrm{y}$ respectively in drilled and dug well drinking waters of Ogun State. Nigeria.

Nwankwo [17] reported annual effective doses in the range of $0.81-1.74 \mathrm{mSv} \mathrm{y}^{-1}$ (with mean value $1.30 \mathrm{mSv} \mathrm{y}^{-1}$ ) in groundwater for adults in Tanke-Ilorin, Nigeria. Ndontchueng et al. [34] reported annual effective doses in the range of 0.009 to $0.159 \mathrm{mSv} \mathrm{y}^{-1}(\bar{x}=0.050$ $\left.\mathrm{mSv} \mathrm{y}^{-1}\right), 0.008$ to $0.147 \mathrm{mSv}^{-1}\left(\bar{x}=0.046 \mathrm{mSv}^{-1}\right)$ and 0.003 to $0.045 \mathrm{mSv}^{-1}(0.015 \mathrm{mSv}$ $\mathrm{y}^{-1}$ ) for infants, children and adults respectively in some mineral bottled water samples produced in Cameroon. All the results show that infants (from birth to $2 \mathrm{y}$ of age) receive 
greater radiation doses from drinking water than adults (> 17 years of age). The accumulation of radiotoxic materials like ${ }^{226} \mathrm{Ra}$ and ${ }^{228} \mathrm{Ra}$ and their precursors and progenies in growing bones of babies and children can cause bone cancers. Humans of all ages that consume these waters face the risk of some health hazards resulting from significant buildup of radium in their bones and other radiosensitive soft body tissues.

The majority of households in the study area do not have access to pipe borne (treated) water supply, they rely on water from these rivers and streams in the region for drinking. So, water from rivers in the study area is not safe for drinking for those age groups.

Fishing and farming are the major occupation of people of the study area. Due to contamination of water bodies in the oil-producing neighboring communities, some fishes in rivers of those regions flow against the current and migrate to rivers in the study area. Hence, the study area provides majority of the fresh water fishes consumed in Ondo State and other neighboring states. The high natural radionuclide content of the river waters of this region can in turn lead to high concentration of these radionuclides in the fishes and other aquatic creatures gotten from the rivers thus increasing the radiological health risk of people consuming the fishes.

\section{Radiological risk due to radium ingestion}

Mass concentration of radium $\left({ }^{226} \mathrm{Ra}\right.$ and $\left.{ }^{228} \mathrm{Ra}\right)$

${ }^{226} \mathrm{Ra}$ and ${ }^{228} \mathrm{Ra}$ mass concentrations in the different drinking river water samples of part of Bitumen belt of Ondo State, Nigeria are displayed in Table 4 and Table 5 respectively. 
Table 4 Radiological and chemical toxicity due to ingestion of ${ }^{226} \mathrm{Ra}$ in river waters of the study area.

\begin{tabular}{|c|c|c|c|c|c|c|}
\hline \multirow[t]{2}{*}{ River Sample location } & \multirow{2}{*}{$\begin{array}{l}\text { Activity } \\
\text { concentration } \\
\left(\mathrm{Bq}^{-1}\right)\end{array}$} & \multirow{2}{*}{$\begin{array}{l}\text { Mass } \\
\text { concentration } \\
\quad \times 10^{-6}\left(\mu \mathrm{g} \mathrm{l}^{-1}\right)\end{array}$} & \multicolumn{2}{|c|}{ Radiological risk } & \multicolumn{2}{|c|}{ Chemical risk } \\
\hline & & & $\begin{array}{l}\text { Mortality } \\
\text { risk }\left(\times 10^{-3}\right)\end{array}$ & $\begin{array}{l}\text { Morbidity } \\
\text { risk }\left(\mathrm{x} 10^{-3}\right)\end{array}$ & $\begin{array}{c}\text { LADD } \\
\times 10^{-14}\left(\mu \mathrm{g} \mathrm{kg}^{-1} \mathrm{~d}^{-1}\right)\end{array}$ & $\begin{array}{l}\text { Hazard Quotient } \\
\times 10^{-14}\end{array}$ \\
\hline \multirow{2}{*}{$\begin{array}{l}\text { Oluwa Opa } \\
\text { Araromi Ayeka }\end{array}$} & 0.12 & 3.29 & 0.04 & 0.04 & 9.39 & 8.38 \\
\hline & 0.58 & 15.90 & 0.19 & 0.20 & 45.43 & 40.56 \\
\hline \multirow{2}{*}{\begin{tabular}{|r|} 
Akeun Ikoya 1 \\
Ikoya 2 \\
\end{tabular}} & 2.31 & 63.33 & 0.77 & 0.80 & 181.01 & 161.61 \\
\hline & 1.77 & 48.54 & 0.59 & 0.61 & 138.02 & 123.23 \\
\hline \multirow{2}{*}{$\begin{array}{|ll|}\text { Ufara } & \text { Oloto 1 } \\
& \text { Oloto 2 } \\
\end{array}$} & 0.82 & 22.52 & 0.27 & 0.28 & 64.13 & 52.26 \\
\hline & 2.18 & 59.70 & 0.72 & 0.75 & 171.20 & 152.86 \\
\hline \multirow{2}{*}{ 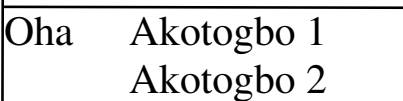 } & 2.03 & 55.61 & 0.67 & 0.70 & 159.66 & 142.55 \\
\hline & 0.58 & 15.92 & 0.19 & 0.20 & 45.43 & 40.56 \\
\hline \multirow{2}{*}{ 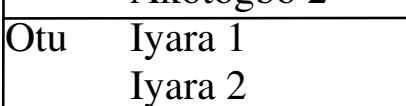 } & 1.09 & 29.81 & 0.30 & 0.38 & 85.31 & 76.17 \\
\hline & 1.31 & 35.94 & 0.44 & 0.45 & 102.33 & 91.36 \\
\hline Minimum & 0.12 & 3.29 & 0.04 & 0.04 & 9.39 & 8.38 \\
\hline Maximum & 2.31 & 59.71 & 0.77 & 0.80 & 181.01 & 161.61 \\
\hline Mean & 1.23 & 35.04 & 0.42 & 0.44 & 100.06 & 89.33 \\
\hline Standard Deviation & 0.72 & 20.9 & 0.26 & 0.26 & 59.82 & 53.30 \\
\hline Standard Error & 0.23 & 6.61 & 0.26 & 0.08 & 18.92 & 16.85 \\
\hline
\end{tabular}


Table 5 Radiological and chemical toxicity due to ingestion of ${ }^{228} \mathrm{Ra}$ in river waters of the study area.

\begin{tabular}{|c|c|c|c|c|c|c|}
\hline \multirow[t]{2}{*}{ River Sample location } & \multirow{2}{*}{$\begin{array}{l}\text { Activity } \\
\text { concentration } \\
\left(\mathrm{Bq} \mathrm{l}^{-1}\right)\end{array}$} & \multirow{2}{*}{$\begin{array}{l}\text { Mass } \\
\text { concentration } \\
\mathrm{x} 10^{-8}\left(\mu \mathrm{g} \mathrm{1^{-1 } )}\right.\end{array}$} & \multicolumn{2}{|c|}{ Radiological risk } & \multicolumn{2}{|c|}{ Chemical risk } \\
\hline & & & $\begin{array}{r}\text { Mortality } \\
\text { risk }\left(\mathrm{x} 10^{-3}\right)\end{array}$ & $\begin{array}{l}\text { Morbidity } \\
\text { risk }\left(\times 10^{-3}\right)\end{array}$ & $\begin{array}{c}\text { LADD } \\
\times 10^{-16}\left(\mu \mathrm{g} \mathrm{kg}^{-1} \mathrm{~d}^{-1}\right)\end{array}$ & $\begin{array}{l}\text { Hazard Quotient } \\
\quad \times 10^{-16}\end{array}$ \\
\hline \multirow{2}{*}{$\begin{array}{l}\text { Oluwa Opa } \\
\text { Araromi Ayeka }\end{array}$} & 0.17 & 1.69 & 0.11 & 0.16 & 4.82 & 4.30 \\
\hline & 0.52 & 5.16 & 0.35 & 0.49 & 14.70 & 13.13 \\
\hline \multirow{2}{*}{$\begin{array}{r}\text { Akeun Ikoya } 1 \\
\text { Ikoya } 2\end{array}$} & 1.78 & 17.63 & 1.18 & 1.66 & 50.41 & 45.01 \\
\hline & 2.77 & 27.50 & 1.84 & 2.59 & 78.50 & 70.09 \\
\hline \multirow{2}{*}{\begin{tabular}{|ll} 
Ufara & Oloto 1 \\
& Oloto 2 \\
\end{tabular}} & 2.29 & 22.72 & 1.52 & 2.14 & 64.91 & 57.96 \\
\hline & 2.85 & 28.30 & 1.89 & 2.66 & 80.70 & 72.05 \\
\hline \multirow{2}{*}{$\begin{array}{ll}\text { Oha } & \text { Akotogbo 1 } \\
& \text { Akotogbo 2 }\end{array}$} & 1.25 & 12.41 & 0.83 & 1.17 & 35.41 & 31.62 \\
\hline & \begin{tabular}{|l|l|}
0.44 \\
\end{tabular} & 4.36 & 0.29 & 0.41 & 12.50 & 11.16 \\
\hline \multirow{2}{*}{$\begin{array}{ll}\text { Otu } & \text { Iyara 1 } \\
& \text { Iyara } 2\end{array}$} & 1.22 & 12.10 & 0.81 & 1.14 & 34.63 & 30.92 \\
\hline & \begin{tabular}{|l|}
1.14 \\
\end{tabular} & 11.34 & 0.76 & 1.07 & 32.32 & 28.86 \\
\hline Minimum & 0.12 & 1.69 & 0.11 & 0.16 & 4.82 & 4.30 \\
\hline Maximum & 2.31 & 28.30 & 1.89 & 2.66 & 80.70 & 70.09 \\
\hline Mean & 1.23 & 14.30 & 0.96 & 1.38 & 40.90 & 36.50 \\
\hline Standard Deviation & 0.72 & 9.48 & 0.63 & 0.95 & 27.10 & 24.20 \\
\hline Standard Error & 0.23 & 3.00 & 0.20 & 0.30 & 8.57 & 7.65 \\
\hline
\end{tabular}


${ }^{226} \mathrm{Ra}$ mass concentration varied from $3.29 \times 10^{-6}$ to $59.70 \times 10^{-6} \mu \mathrm{g} \mathrm{1^{-1 }}$ with a mean value of $35.04 \times 10^{-6} \mu \mathrm{g} \mathrm{1^{-1 }}$ while that of ${ }^{228}$ Ra varied from $1.69 \times 10^{-8} \mu \mathrm{g} \mathrm{l^{-1 }}$ to $28.30 \times 10^{-8} \mu \mathrm{g} \mathrm{l^{-1 }}$ with a mean value of $14.30 \mu \mathrm{g} \mathrm{l}^{-1}$. The variations may be attributable to differences in local geology of the source of river, geographical location or depth of sample collection. The tables show that all the water samples have ${ }^{226} \mathrm{Ra}$ and ${ }^{228} \mathrm{Ra}$ mass concentration below the $20 \mu \mathrm{g}^{-1}$ limit set for Canada [14,24,35], the $30 \mu \mathrm{g} \mathrm{l}^{-1}$ limit recommended by WHO [13], the permissible limit set for drinking water in the USA [36] and the $60 \mu \mathrm{g} \mathrm{l}^{-1}$ limit set for India[37].

\section{Lifetime cancer risks}

The lifetime cancer risks associated with the ingestion of ${ }^{226} \mathrm{Ra}$ and ${ }^{228} \mathrm{Ra}$ radium in the drinking waters of the rivers were evaluated in terms of mortality and morbidity risks. While cancer mortality risk concerns deaths with cancer as the underlying cause in a specified population, morbidity risk is concerned with the amount of cancer within the population. The calculated cancer mortality risk due to the ingestion of ${ }^{226} \mathrm{Ra}$ are displayed in Table 4, and ranged from $0.04 \times 10^{-3}$ to $0.77 \times 10^{-3}$ with mean value of $0.42 \times 10^{-3}$ whereas cancer morbidity risk ranged from $0.04 \times 10^{-3}$ to $0.80 \times 10^{-3}$ with a mean value of $0.44 \times 10^{-3}$. Table 5 shows the calculated cancer mortality due to the ingestion of ${ }^{228} \mathrm{Ra}$ in the water sampled ranged from $0.11 \times 10^{-3}$ to $1.89 \times 10^{-3}$ with a mean value of $0.96 \times 10^{-3}$ while its morbidity risks ranged from $0.16 \times 10^{-3}$ to $2.66 \times 10^{-3}$ with a mean value of $1.38 \times 10^{-3}$. The mean values of both lifetime cancer risks due to ingestion of both ${ }^{226} \mathrm{Ra}$ and ${ }^{228} \mathrm{Ra}$ in the water samples were below the maximum limit of $1.0 \times 10^{-3}$ specified by USNRC [38]. About $40 \%$ of the water samples display ${ }^{228} \mathrm{Ra}$ cancer mortality risk values above the maximum limit of $1.0 \times 10^{-3}$ specified USNRC [38] while up to $70 \%$ exhibit cancer morbidity risk above $1.0 \times 10^{-3}$

USNRC limit. The mean carcinogenic risks values of $0.42 \times 10-3$, and $0.44 \times 10^{-3}$ (mortality) and $1.38 \times 10^{-3}$ (morbidity) in this study area are higher than those reported for Odeda Area 
$\left(1.46 \times 10^{-4}\right.$ and $2.24 \times 10^{-4}$ respectively) by Amakom and Jibiri [39] and Ago-Iwoye (1.09 $\times 10^{-4}$ and $1.68 \times 10^{-4}$ respectively) by Alausa et al. [40] in Nigeria..

\section{Chemical toxicity}

\section{Lifetime Average Daily Dose}

The calculated lifetime average daily dose (LADD) due to the ingestion of ${ }^{226} \mathrm{Ra}$ and ${ }^{228} \mathrm{Ra}$ in the drinking waters displayed in tables 4 and 5 respectively varied from $9.39 \times 10^{-14}$ to $181.01 \times 10^{-14} \mu \mathrm{g} \mathrm{kg}{ }^{-1} \mathrm{~d}^{-1}$ with a mean value of $100.06 \times 10^{-14} \mu \mathrm{g} \mathrm{kg}^{-1} \mathrm{~d}^{-1}$ for ${ }^{226} \mathrm{Ra}$ while it varied from $4.82 \times 10^{-16}$ t0 $80.70 \times 10^{-16} \mu \mathrm{g} \mathrm{kg}^{-1} \mathrm{~d}^{-1}$ with a mean value of $40.90 \times 10^{-16} \mu \mathrm{g} \mathrm{kg}^{-1} \mathrm{~d}^{-}$ ${ }^{1}$ for ${ }^{228} \mathrm{Ra}$.The mean values of LADD obtained in this study are much lower than the maximum permissible value of $1.0 \mu \mathrm{g} \mathrm{kg}^{-1} \mathrm{~d}^{-1}$ recommended for drinking water by WHO [13]. The data presented in tables 4 and 5 show that all of the river water samples have LADD values that are very much lower than the WHO permissible limit.

\section{Hazard Quotient}

The hazard quotient (HQ) values estimated using $\mathrm{R}_{\mathrm{f}} \mathrm{D}$ value of $1.12 \mu \mathrm{g} \mathrm{kg}^{-1} \mathrm{~d}^{-1}$ recommended by WHO [13] ranged from $8.38 \times 10^{-14} \mu \mathrm{g} \mathrm{kg}^{-1} \mathrm{~d}^{-1}$ to $161.61 \times 10^{-14} \mu \mathrm{g} \mathrm{kg}^{-1} \mathrm{~d}^{-1}$ with a mean value of $89.33 \times 10^{-14} \mu \mathrm{g} \mathrm{kg}^{-1} \mathrm{~d}^{-1}$ for ${ }^{226} \mathrm{Ra}$ and $4.30 \times 10^{-16}$ to $70.09 \times 10^{-16} \mu \mathrm{g} \mathrm{kg}^{-1} \mathrm{~d}^{-1}$ with a mean value of $36.50 \times 10^{-16} \mu \mathrm{g} \mathrm{kg}^{-1} \mathrm{~d}^{-1}$ for ${ }^{228} \mathrm{Ra}$ All river water samples in the study area showed HQ values much lower than 1 .

\section{Conclusion}

The results obtained in this study show that the total annual effective doses of radiation from investigated drinking river water samples to all age groups exceed the $0.1 \mathrm{mSv} \mathrm{y}^{-1}$ safe limit set by WHO [13] and the $1.0 \mathrm{mSv} \mathrm{y}^{-1}$ limit set by ICRP [20] for drinking water. They also indicate that the mass concentrations of ${ }^{226} \mathrm{Ra}$ and ${ }^{228} \mathrm{Ra}$ in all the samples are below the 30 $\mu \mathrm{g}^{-1}$ permissible limit set by WHO [13]. Whereas about $40 \%$ of the water samples display ${ }^{228} \mathrm{Ra}$ cancer mortality risk values above the maximum limit of $1.0 \times 10^{-3}$ specified USNRC 
[39], up to $70 \%$ exhibit cancer morbidity risk above $1.0 \times 10^{-3}$ USNRC limit. All the river water samples collected from the study area show lifetime average daily dose and hazard quotient values lower than the acceptable limit of 1.0. Therefore, the radiological toxicity of radium should be a matter of more interest to the population in the study area than its chemical toxicity risks. 


\section{References}

1. United Nations Scientific Committee on the Effects of Atomic Radiation (UNSCEAR) Sources and effects of ionizing radiation. UNSCEAR 2000 Report Vol. 1 to the General Assembly, with scientific annexes. New York: United Nations. (2000)

2. World Health Organization (WHO) Guidelines for drinking water quality. Vol. 1. Recommendations (Geneva: WHO) (1993)

3. Brugge, D. \& Buchner, V. Radium in the environment: Exposure pathways and health effects. Rev. Environ. Health. 27(1), 1-17 (2012)

4. Amin, S. A. \& Jassim, A. A. Radium isotopes levels in drinking water samples. Engrg. and Tech. Journ. 35, Part B (1), 46-49 (2017)

5. Kim, G., Burnett. W. C., Dulaiova, H., Swarzenski, P. W. \& Moore, W. S. Measurement of ${ }^{224} \mathrm{Ra}$ and ${ }^{226} \mathrm{Ra}$ activities in natural waters using a radon-air monitor. Environ.Sci. Tech. 35, 4680-4683 (2001)

6. Abbasi, A. \& Bashiry, V. Measurement of radium-226 concentration and dose calculation of drinking water samples in Guilan province of Iran. Int. J. Radiat. Res. 14(4), 361-366 (2016)

7. Abbasi, A, \& Mirekhtiary, F. Lifetime risk assessment of Radium-226 in drinking water samples. Int. J. Radiat. Res. 17(1), 163-169 (2019)

8. Binesh, A. \& Arabshashi, A., Pourhabib, Z. Radioactivity and dose assessment of heavy radioactive pollution, radon and radium from water sources of 3 northern regions in Iran Int. J. Phys. Sci. 6(35), 7969-7977. (2011)

9. Maxwell, O. et al. Radiotoxicity risks of radium-226 $\left({ }^{226} \mathrm{Ra}\right)$ on ground-based drinking atDawaki, Kuje, Giri and Sabon-Lugbe area of Abuja, North Central Nigeria. Envron. Earth Sci. 75, 1082 (2016)

10. Committee on the Biological Effects of Ionizing Radiation.(CBEIR) Health risks of radon and other internally deposited alpha emitters (BEIRIV). Washington, DC.National Academy Press, 276-302 (1988)

11. International Atomic Energy Agency (IAEA) The Environmental behavior of radium. Revised Edition. Technical Reports Series.No. 476 (2014)

12. United States Environmental Protection Agency (USEPA) National Primary Drinking Water Regulations; Radionuclides, Final Rule. 40 CFR parts 9, 141 and 142, pp. 76708-76712 (2000)

13. World Health Organization (WHO). Uranium in Drinking water, Background document for development of WHO guidelines for drinking water quality. (2011)

14. Health Canada. Uranium in Drinking Water. Document for Public comments. Prepared by the Federal Provincial Subcommittee on Drinking Water. (1999)

15. Adekoya, O. I. Primordial radionuclides in potable watee from former tin-mining areas with elevated activity Int. J. Phy. Sci. 9(3), 506-511 (2014)

16. Agaja, S. A, \& Ajisafe, J. I. Natural radioactivity of surface and ground water samples in coastal communities of Delta State, Nigeria. Int. J. Curr. Res. 5(12), 40574061 (2013)

17. Nwankwo, L. I. Determination of natural radioactivity in groundwater in TankeIlorin, Nigeria. West African J. of Appl. Ecol. 21(1), 111-119. (2013)

18. Rahaman, M. A. Recent advances in the study of the basement complex of Nigeria', Precambrian: Geology of Nigeria, Pub. of Geol. Sur. of Nigeria 3, 11-34. (1988) 
19. Awudu, A. R. et al. Determination of activity concentration levels of ${ }^{238} \mathrm{U},{ }^{232} \mathrm{Th}$ and ${ }^{40} \mathrm{~K}$ in drinking water in a gold mine in Ghana. Operational Radiation Safety. Health Phys. 99(2), 149-153. (2010)

20. International Commission on Radiological Protection (ICRP) Compendium of Dose Coefficient based on ICRP Publication 60. ICRP Publication 119. Ann. ICRP (Suppl.). (2012)

21. World Health Organization (WHO) Meeting the MDG drinking Water and Sanitation Target: The Urban and Rural Challenge of the Decade. WHO Geneva. (2008)

22. Singh, L., Kumar, R., Kumar, S., Bajwa, B. S. \& Singh, S. Health risk assessments due to uranium contamination of drinking water in Bathinda region, Punjab State, India. Radioprotect. Doi:10.1051/radiopro/2012042. 48(2), 191-202. (2012)

23. Environmental Protection Agency (EPA) Cancer risk coeficiens for Environmental exposure to radionuclides, Federal Guidance Report No. 13 (EPA 402 R99-001) (1999)

24. Ye-shin, K. et al. Health risk assessment for uranium in Korean groundwater. J. of Environ. Radioact. 77, 77-85 (2004)

25. Lee, J. S., Chon, H. T. \& Kim, K. S. Human risk assessment of As, Cd, Cu, and Zn in the abandoned metal mine site. Environ. Geochem. and Health 27, 186-191 (2005)

26. World Health Organization (WHO) Guidelines for drinking water quality, $3^{\text {rd }}$ Edition. Vol 1. Recommendations. Geneva. (2004)

27. International Atomic Energy Agency (IAEA) Specification of Radionuclide content in Commodities Requiring Regulation for Purposes of Radiation Protection. Safety Guide (Draft), Vienna. (2002)

28. World Health Organization (WHO) Guideline for drinking water quality Vol. 1. Recommendations (Geneva: WHO) (1993)

29. International Commission on Radiological Protection (ICRP) Protection of the public in situations of prolonged radiation exposure. ICRP Publication 82. Ann ICRP 29(1-2) (Elsevier) (2000)

30. Achuka, J. A., Usikalu, M. R. \& Oyeyemi, K. D. Radiological risks assessment of Ogun State drinking water. American J. Appl. Sci. 14(5), 540-550 (2017)

31. Ajayi, O. S. \& Adesida, G. Radioactivity in some sachet drinking water samples produced in Nigeria. Iranian J. of Radiat. Res. 7(3), 151-158 (2009)

32. Ajayi, O. S. \& Owolabi, T. P. Determination of natural radioactivity in drinking water in private dug wells in Akure. Southwestern Nigeria. Radiat. Prot. Dosim. 128(4), 477-484 (2008)

33. Ajayi, O. S. \& Achuka, J. A. Radioactivity in drilled and dug well drinking water of Ogun State. Southwestern Nigeria and consequent dose estimates. Radiat. Prot. Dosim. 135(1), 54-63 (2009)

34. Ndontchueng, M. M., Simo, A., Nguelen, E. J. M., Beyala, J. F. \& Kryeziu, D. Preliminary study of Natural radioactivityand radiological risk assessment in some mineral bottled water produced in Cameroon. Int. J. of Sci. and Tech. 3(5), 271-276 (2013)

35. Gilman, A. P. et al. Uranyl nitrate: 28-day and 91-day toxicity studies in the Sprague-Dawley rat. Toxicol. Sci. 41, 117-128 (1998)

36. United States Environmental Protection Agency (USEPA). Current Drinking Water Standards. Groundwater and drinking water Protection Agency. Pp. 1-12.

37. Atomic Energy Regulatory Board (AERB) (2004) Directive for Limit on Uranium in 
Drinking Water, Department of Atomic Energy, Government of India. (2003)

38. United States Nuclear Regulatory Commission and U.S. Environmental Protection Agency (USNRC) White paper on Risk Harmonization. Final report jointly prepared by NRE and EPA, copy of paper obtained from EPA (1995)

39. Amakom, C. M. \& Jibiri, N. N. Chemical and radiological risk assessment of uranium in borehole and well waters in Odeda Area, Ogun State. Nigeria. Int. J. of the Phys. Sci. 5(7), 1009-1014. (2010)

40. Alausa, S. K., Fasuwon, O. O. \& Odunaike, K. Activity and corresponding mass concentration of ${ }^{40} \mathrm{~K}$ and ${ }^{238} \mathrm{U}$ in well waters from Ago-Iwoye, Ogun State. Nigeria. J. of Nat. Sci. Res. 4(12), 1-5. (2014) 


\section{AUTHOR CONTRIBUTIONS STATEMENT}

Conception of the work

Design of the work (Methodology)

Acquisition, analysis and investigation

Interpretation of data

Writing - Original draft, preparation

Writing - Review and editing

Revision

Supervision
A.O.S

A.O.S

A.OS. \& O.O.Y

A.O.S.

O.O.Y \& A.O.S

A.O.S

A.O.S \& O.O.Y

A.O.S

\section{ADDITIONAL INFORMATION}

Conflicts of interest/ competing interest: None

Funding: No funding was received for conducting this study

\section{LEGENDS}

\section{Main Figures}

Fig. 1 Average Annual Effective Dose to Different age groups from river water consumption

Fig. 2 Average Annual Effective Dose from the rivers

\section{Main Tables}

Table 1 Dose conversion factors $\left(\mathrm{Sv} \mathrm{Bq}{ }^{-1}\right)$ for ingested natural radionuclides for the general public.

Table 2 Activity concentrations of radionuclides in the water samples and total annual effective dose to different age groups

Table 3 Minimum, maximum and mean activity concentrations of ${ }^{226} \mathrm{Ra},{ }^{228} \mathrm{Ra}$ and ${ }^{40} \mathrm{~K}$ in the river water samples

Table 4 Radiological and chemical toxicity due to ingestion of ${ }^{226} \mathrm{Ra}$ in river waters of the study area.

Table 5 Radiological and chemical toxicity due to ingestion of ${ }^{228} \mathrm{Ra}$ in river waters of the study area. 
Figures

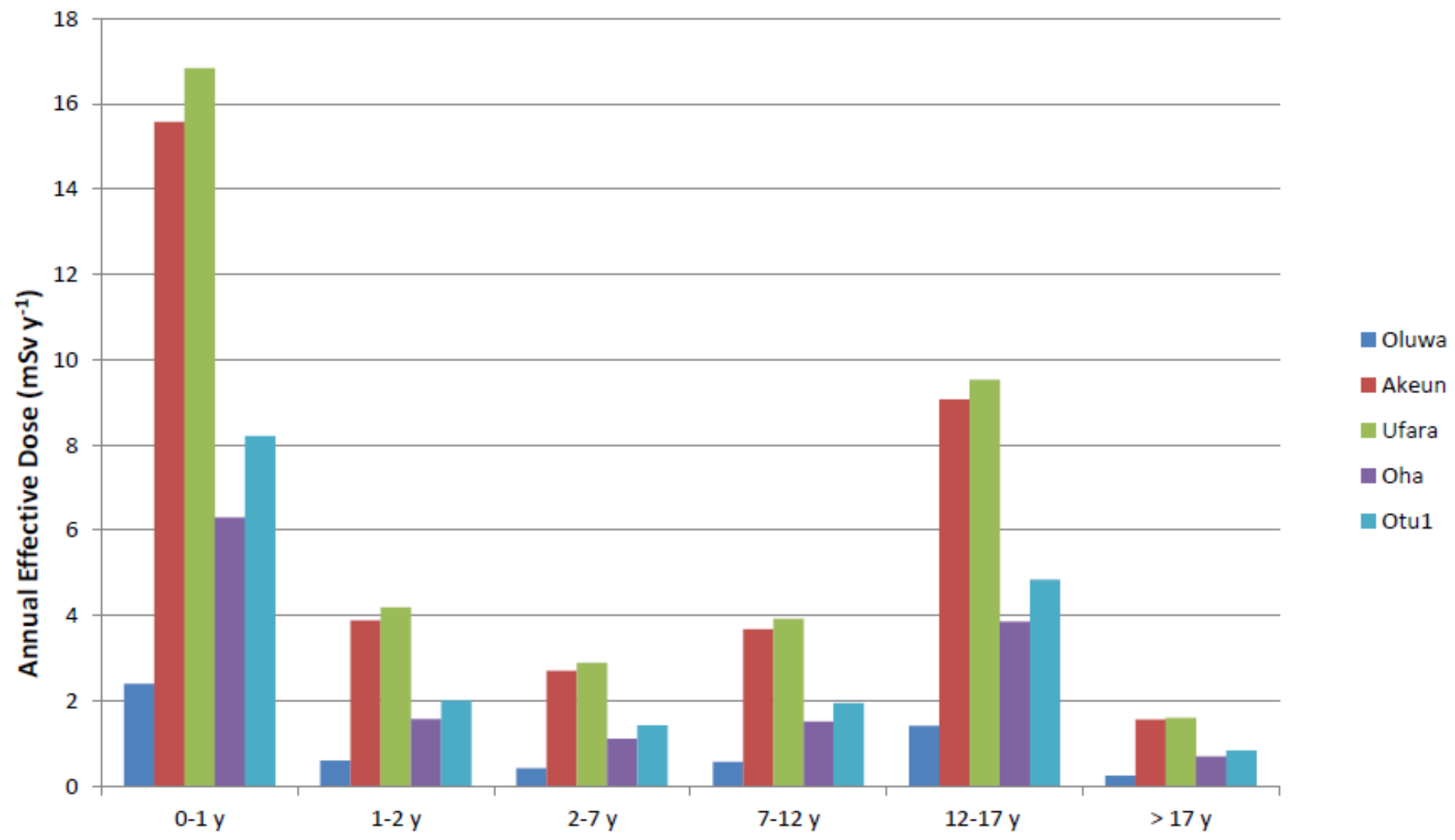

Figure 1

Average Annual Effective Dose to Different age groups from river water consumption

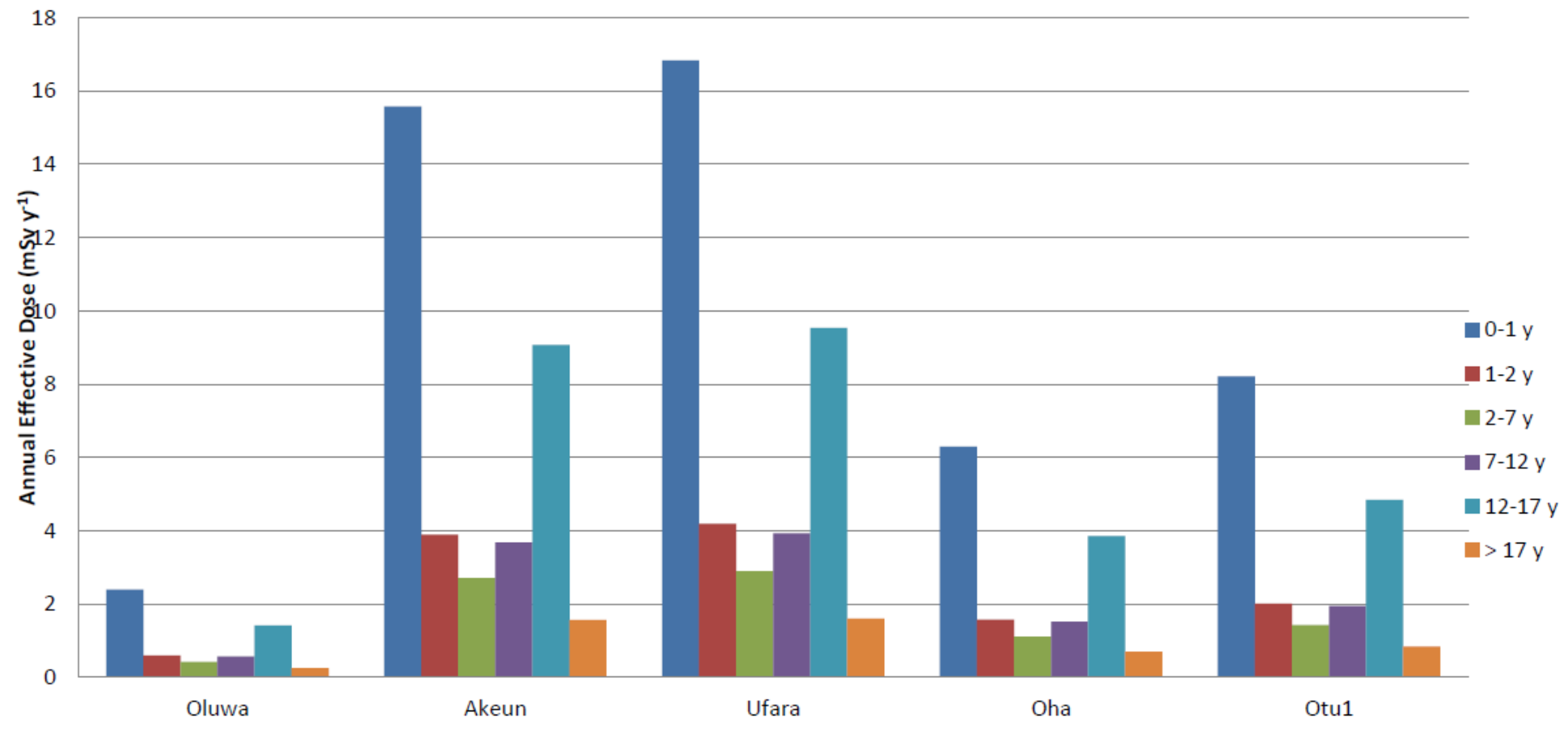

Figure 2 
Average Annual Effective Dose from the rivers 